\title{
8
}
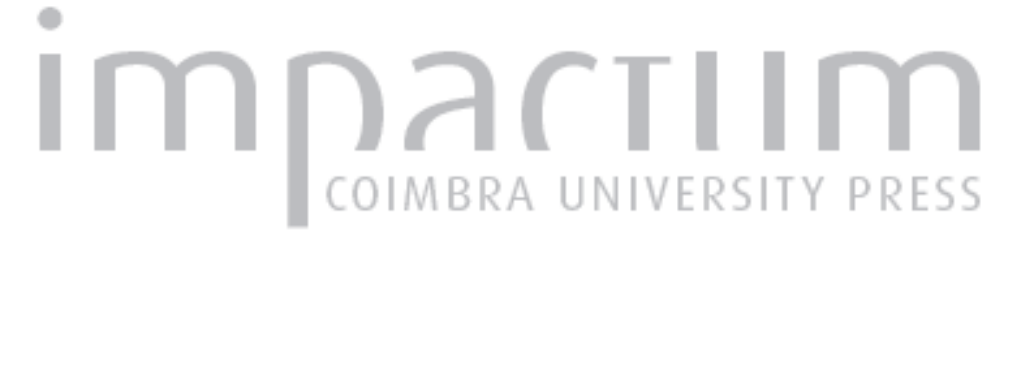

\section{Ruptura, instauratio, idola e obstáculos: historicidade, crises, o sujeito epistémico e o poder da ciência}

\author{
Autor(es): $\quad$ André, João Maria
}

Publicado por: Faculdade de Letras da Universidade de Coimbra

URL persistente:

URI:http://hdl.handle.net/10316.2/32267

DOI:

DOI:http://dx.doi.org/10.14195/0870-4112_10_1

Accessed : $\quad$ 26-Apr-2023 05:43:09

A navegação consulta e descarregamento dos títulos inseridos nas Bibliotecas Digitais UC Digitalis, UC Pombalina e UC Impactum, pressupõem a aceitação plena e sem reservas dos Termos e Condições de Uso destas Bibliotecas Digitais, disponíveis em https://digitalis.uc.pt/pt-pt/termos.

Conforme exposto nos referidos Termos e Condições de Uso, o descarregamento de títulos de acesso restrito requer uma licença válida de autorização devendo o utilizador aceder ao(s) documento(s) a partir de um endereço de IP da instituição detentora da supramencionada licença.

Ao utilizador é apenas permitido o descarregamento para uso pessoal, pelo que o emprego do(s) título(s) descarregado(s) para outro fim, designadamente comercial, carece de autorização do respetivo autor ou editor da obra.

Na medida em que todas as obras da UC Digitalis se encontram protegidas pelo Código do Direito de Autor e Direitos Conexos e demais legislação aplicável, toda a cópia, parcial ou total, deste documento, nos casos em que é legalmente admitida, deverá conter ou fazer-se acompanhar por este aviso.

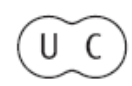



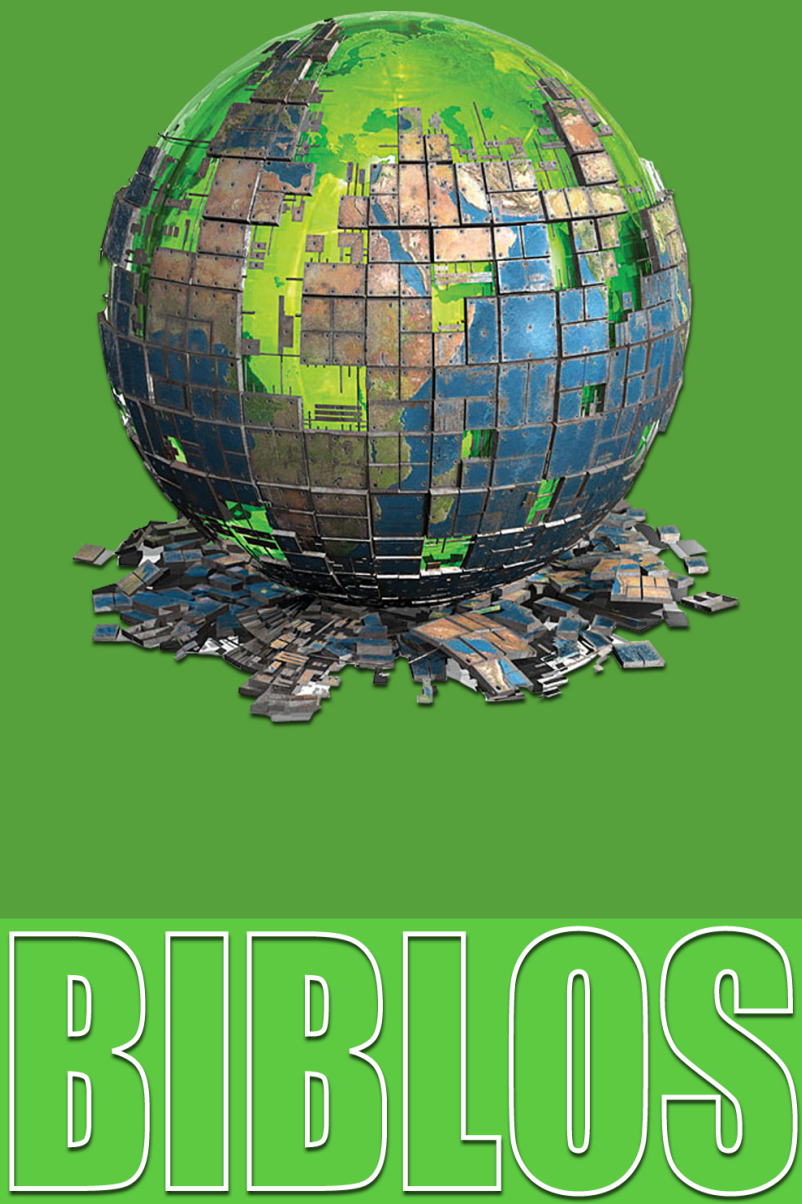

$\frac{\text { REVISTA DA FACULDADE DE LETRAS }}{\text { UNIVERSIDADE DE COIMBRA }}$ 
Biblos, n. s. X (2012) $\ldots-\ldots$

João MARIA ANDRÉ

Faculdade de Letras da Universidade de Coimbra

\title{
RUPTURA, INSTAURATIO, IDOLA E OBSTÁCULOS: Historicidade, crises, o sujeito epistémico e o poder da ciência
}

à Doutora Marina Ramos Themudo

\section{Resumo}

Neste texto procuramos tirar partido de uma reflexão sobre os episódios de crise no processo do desenvolvimento histórico e temporal da ciência, para repensar a natureza do sujeito epistémico, o seu poder e limites, e o poder e os limites da própria ciência. Para isso, centramo-nos em dois filósofos, separados por quatro séculos, mas que, ao aprofundarem a natureza da crise do conhecimento e da ciência que a sua inscrição histórica lhes permitiu presenciar, apresentam alguns traços em comum: Francis Bacon, por um lado, e Gaston Bachelard, por outro. Assim, debruçamo-nos em primeiro lugar sobre os conceitos de de ruptura epistemológica e de obstáculos epistemológicos de Bachelard, em segundo lugar sobre os conceitos de instauratio e de idola na "Filosofia da Ciência" produzida por Francis Bacon e sobre as suas implicações filosófico-antropológicas, para terminarmos com uma reperspectivação do sujeito epistémico à luz das análises do filósofo francês.

Palavras-Chave: Ruptura Epistemológica, Revolução Científica, Obstáculos Epistemológicos, Ídolos de Bacon, Sujeito Epistémico.

\begin{abstract}
In this text, we depart from a reflection on episodes of crisis in the process of science's historic and temporal development to rethink the nature of the epistemic subject, its power and limits, and the power and limits of science itself. The focus lies on two philosophers who are four centuries apart but who present several traces in common since they both have delved into the nature of

* Este texto corresponde, no essencial, à nossa lição de agregação em Filosofia, apresentada à Faculdade de Letras da Universidade de Coimbra em Julho de 2001. Propusemo-nos publicá-lo, há alguns anos, num volume de homenagem à Doutora Marina Ramos Themudo, o qual, infelizmente, não chegou a ser editado. Continuamos a retomá-lo aqui como testemunho da nossa homenagem a essa professora e mestre, com a gratidão de quem foi seu aluno e colega e com o afecto de quem se sente honrado com a sua amizade.
\end{abstract}


the crisis of knowledge and science that their historic inscription allowed them to be witnesses of: Francis Bacon and Gaston Bachelard. First, the analysis centres on Bachelard's concepts of epistemological break and epistemological obstacles, to move on to the concepts of instauratio and idola in Francis Bacon and their philosophical-anthropological implications and, finally, to conclude with a reperspectivation of the epistemic subject under the light of the French philosopher's analyses.

Keywords: Epistemologic Break, Scientific Revolution, Epistemological Obstacles, Bacon Idola, Epistemic Subject. 


\section{Introdução}

Tempo e crise suscitam, no contexto da História da Ciência, a problemática da natureza dos episódios que, sobretudo após a publicação da célebre obra de Thomas Kuhn em 1962, nos habituámos a designar com a expressão "revoluções científicas" e que a epistemologia histórica de Bachelard já analisara antes ao focar a transição dos estados de desconhecimento para os estados de conhecimento ou dos estados de menor conhecimento para os estados de um maior conhecimento, transição essa pensada em termos de "ruptura epistemológica". Não se trata de uma reflexão inteiramente nova no panorama filosófico ocidental e poderia dizer-se que, já em plena época de uma das maiores revoluções científicas, a revolução do século XVII, autores houve que se debruçaram sobre a natureza dessas transições, interrogando não só a ciência, mas equacionando, de modo implícito ou explícito, o respectivo sujeito epistémico, o papel que ele representa nesses momentos de crise e o poder que assume para os resolver. Por isso, quando se pensam, no contexto da actividade científica, as categorias de tempo e de crise, pensa-se simultaneamente o homem, sujeito da ciência, de tal maneira que, em contexto epistemológico, essas categorias remetem para a dimensão antropológica da ciência, para a articulação entre ciência e poder e, por isso mesmo, para a potência e os limites do sujeito humano historicamente situado num processo feito de avanços e recuos, de dúvidas e hesitações, de certezas e de incertezas. Vamos, por isso, tentar interrogar as categorias de tempo e crise através da interrogação da própria ciência e da sua dimensão histórica em dois momentos decisivos da tradição histórico-científica europeia: a passagem do século XVI para o século XVII (através de Francis Bacon, que foi uma das suas consciências históricas) e a transição ocorrida em pleno século $\mathrm{XX}$, com implicações macroparadigmáticas que se estenderam a todos os campos do saber e da reflexão filosófica (através de Gaston Bachelard, que pensou essa transição no próprio momento do seu acontecimento).

Ora, uma das formas de interrogar a ciência é, sem dúvida, equacionar a problemática que envolve a definição do seu sujeito. Se a aventura da Ciência Moderna começa com o processo de instauração do dualismo entre o sujeito e o objecto do conhecimento e com a transformação do sujeito do conhecimento em árbitro da inteligibilidade do real, esse sujeito epistémico terá sido tão reduzido ou dissolvido ao longo 
das últimas décadas em algumas das concepções que pretendem dar conta do que é a ciência que nos parece legítimo retornar a ele para o reencontrar a partir da dupla contextualização que nos é oferecida pela inscrição histórica e sociológica da investigação científica.

Não deixa de ser interessante constatar que, no mesmo ano em que se desenha uma distinção decisiva para o projecto epistemológico do Empirismo Lógico, é também publicado um livro fundamental no sentido contrário ao que é esboçado nesse projecto. Estamos em 1938 e Reichenbach, caracterizando a tarefa dos epistemólogos como uma "reconstrução lógica", afirma que tal "reconstrução lógica corresponde à forma como os processos de pensamento são comunicados a outras pessoas em vez de corresponder à forma como são subjectivamente conformados", acrescentando logo a seguir: "Introduzirei os termos de contexto de descoberta e contexto de justificação para fazer esta distinção. Portanto, temos de dizer que a epistemologia só se ocupa em construir o contexto de justificação". Por esta mesma altura, num quadro filosófico diferente, emergem e afirmam-se as epistemologias históricas e, precisamente no mesmo ano de 1938, publica Gaston Bachelard também um livro que aprofundará uma categoria epistemológica central no pensamento do seu autor e fará fortuna nas décadas seguintes, marcado pela preocupação por construir uma imagem da ciência tal como acontece, in fieri. Trata-se da categoria de obstáculo epistemológico e da noção de ruptura que lhe anda associada. Ao fazê-lo e ao apresentar as crises de crescimento do pensamento na sua exigência de uma refontização total do sistema do saber é não só a epistemologia que é reformulada, mas, com a epistemologia, é também o próprio sujeito epistémico que é profundamente questionado, já que, como refere o autor, "pelas revoluções espirituais a que obriga a invenção científica, o homem torna-se uma espécie de mutante, ou melhor ainda, uma espécie que tem necessidade de mudar e que sofre por não mudar."2

${ }^{1}$ H. ReIChenbach, Experience and Prediction, Chicago, University of Chicago Press, 1938, pp. 6-7.

${ }^{2} \mathrm{G}$. Bachelard, La formation de l'esprit scientifique. Contribution à una psychanalyse de la connaissance, 16 a ed., Paris, Vrin, 1996, p. 14. 
A tendência a que, na formulação de Harold Brown ${ }^{3}$, se veio a chamar "a nova filosofia da ciência", protagonizada por autores como Thomas Kuhn, Imre Lakatos ou Paul Feyerabend, mas prefigurada, no final da década de cinquenta por Hanson ${ }^{4}$ e, ainda mais remotamente, nos anos trinta por Ludwik Fleck ${ }^{5}$, depressa fez passar ao esquecimento o trabalho profundamente inovador e hoje insuficientemente conhecido e talvez injustamente não reconhecido desenvolvido ao longo de cerca de quatro décadas por Gaston Bachelard ${ }^{6}$. Mais ainda: quer as posições de autores que prolongam a visão empirista do mundo, como W. V. Quine, com o continuismo epistemológico que lhe anda associado, bem expresso na tese de que "a ciência é ela própria a continuação do senso comum" e de que "o cientista é indistinguível do homem comum no seu sentido de evidência, excepto que o cientista é mais cuidadoso" ", quer a proposta do novo paradigma para uma ciência pós-moderna assente numa segunda ruptura epistemológica que visaria reabilitar o senso comum, ainda que sob uma forma mais esclarecida e, em certo sentido, sensocomunizar a ciência, como aquela que é apresentada por Boaventura Sousa Santos ${ }^{8}$, são propostas que tendem a subalternizar a

${ }^{3}$ Cf. H. Brown, La nueva filosofía de la ciencia, Trad. de G. Solana e H. Marraud, Madrid, Tecnos, 1977.

${ }^{4}$ Cf. N. R. Hanson, Patterns of Discovery: an Inquiry into the Conceptual Foundations of Science, Cambridge, Cambridge University Press, 1958.

${ }^{5} \mathrm{Cf}$. Ludwik FLECK, Entstehung und Entwicklung einer wissenchaftlichen Tatsache: Einfuihrung in die Lehre vom Denkstil und Denkkollektiv, Basel, Benno Schwabe, 1935. Sobre o carácter antecipatório das teses de Fleck relativamente a Kuhn, cf. Paolo ROSSI, Las arañas y las hormigas. Una apologia de la história de la ciencia, trad. de Joana Bignozzi, Barcelona, Editorial Crítica, 1990, pp. 56-88.

${ }^{6}$ Apesar de esquecido, Bachelard não deixou de influenciar bastante a Epistemologia do século XX. Sobre a recepção da obra de Bachelard cf. Jean GAYON e Jean-Jacques Wunemburger (eds.), Bachelard dans le monde, Paris, PUF, 2000.

7 W. V. Quine, "O alcance e a linguagem da ciência”, in Filosofia e linguagem, organização e apresentação de João Sàágua, trad. de João Sàágua e Rui Silva, Porto, Edições Asa, 1995, p. 25.

${ }^{8}$ Diz Boaventura de Sousa SAnTos em Um discurso sobre as ciências, $4^{\text {a }}$ edição, Porto, Edições Afrontamento, 1990, p. 57: "Na ciência moderna a ruptura epistemológica simboliza o salto qualitativo do conhecimento do senso comum para o conhecimento científico; na ciência pós-moderna o salto mais importante é o que é dado do conhecimento científico para o conhecimento do senso comum". Na mais recente retomada das ideias expressas nesta obra ( $A$ crítica da razão indolente. Contra o desperdício da experiência, Porto, Edições Afrontamento, 2000), o mesmo autor esclarece melhor a sua tese ao referir este 
importância e, eventualmente, a actualidade epistemológica das posições de Bachelard ou de outras que estejam em convergência com elas. Há trinta e dois anos, Dominique Lecourt perguntava, ao concluir a introdução à sua "Mémoire de Maîtrise" sobre a Epistemologia Histórica de Gaston Bachelard: "Por que razão ler Gaston Bachelard em 1968?" Idêntica pergunta parece, pelo que acabámos de dizer, ter hoje ainda o seu cabimento, mas a resposta a ela poderá continuar a ser esta: porque, se a obra de Bachelard indicia, na época em que foi produzida, a instauração de uma problemática epistemológica nova, ela proporciona ainda hoje uma reflexão fecunda sobre os limites e o poder da ciência centrada na definição do sujeito epistémico e consequentemente também nos limites e no poder desse mesmo sujeito.

O esforço de Bachelard, no projecto que anuncia, prende-se, como igualmente sublinhou o mesmo Lecourt no seu Concurso de Agregação em Filosofia em 1974, com a ideia de que, no contexto de uma Filosofia da Ciência pensada em nome e a partir das ciências contemporâneas, "é necessário renunciar à concepção clássica da Razão" 10 , o que o leva a intitular algumas das suas obras com expressões bem elucidativas sobre o seu propósito de demarcação, como é o caso de Le nouvel esprit scientifique, publicada em 1934, ou La philosophie du nonEssai d'une philosophie du nouvel esprit scientifique, datada de 1940. Para concretizar esse projecto, o autor centra-se nos momentos em que é possível captar o modo de funcionamento da razão científica quer no limiar da cientificidade da sua prática e do seu discurso, quer nos passos através dos quais efectiva a rectificação dos caminhos anteriormente percorridos. Pensando o desenvolvimento da ciência em termos de ruptura e dos respectivos obstáculos, equaciona-se o poder e a natureza

novo senso comum como um senso comum emancipatório "construído para ser apropriado privilegiadamente pelos grupos sociais oprimidos, marginalizados ou excluídos e, de facto, alimentado pela prática emancipatória destes” (p. 102). Todavia, esta distinção entre a construção do senso comum e a sua apropriação pelos grupos sociais oprimidos, deixa-nos algumas dúvidas sobre a natureza de tal senso comum cujo sujeito construtor parece ser diferente do sujeito da respectiva apropriação, sem sabermos efectivamente o que faz dele um senso comum e o que o torna realmente emancipatório.

${ }^{9}$ Dominique Lecourt, L'épistémologie historique de Gaston Bachelard, Paris, Vrin, 1974, p. 15.

${ }^{10}$ Cf. idem, Bachelard ou le jour et la nuit, Paris, Bernard Grasset, 1974, p. 38. 
do sujeito epistémico com base nos pressupostos em que assenta o seu trabalho científico e na relação que o produto final mantém com esses mesmos pressupostos, mas, ao mesmo tempo, é a realização histórica e social da ciência como poder que progressivamente passa a primeiro plano, recolocando a reflexão filosófica sobre o conhecimento científico no plano da sua dimensão ontogénica e realizadora e no horizonte da sua indissociável relação com a técnica.

Significa isto que é todo o projecto da Ciência Moderna que é equacionado por Bachelard, precisamente no momento em que os seus limites se tornam mais evidentes e se desenham múltiplas tentativas para a sua superação e algumas alternativas consistentes susceptíveis de se contrapor ao seu paradigma dominante. Mas, ao fazê-lo, o autor actua de uma maneira profundamente dialéctica, na medida em que, por um lado, a sua epistemologia "representa o máximo de consciência possível do paradigma da ciência moderna"11, por outro lado, estabelece, pela afirmação da descontinuidade do desenvolvimento da ciência, algumas condições e pressupostos que contribuirão para a crise desse mesmo paradigma e, por outro lado ainda, perfila-se de uma forma conflitual e de certo modo contraditória relativamente a alguns dos autores extremamente significativos no delineamento de certos traços da matriz epistemológica em vigor até meados do século XX. O mais característico dessa conflitualidade e dessa contradição é que ela não significa apenas ruptura mas simultaneamente herança e continuidade, ainda que não explicitamente assumidas mas tão simplesmente presentes de uma forma velada em algumas das categorias centrais da sua "nova filosofia do espírito científico" e sobretudo nos termos em que a natureza, o poder e os limites do sujeito epistémico se reflectem na concepção de ciência activada.

Isso torna-se mais evidente quando nos centramos na forma como ele se relaciona com dois grandes autores da primeira metade do Século XVII, que os compêndios de Filosofia e de História das Ideias nos habituaram a situar em campos opostos: Bacon e Descartes.Aum e a outro e às posições epistemológicas de um e de outro consagrou o pensador francês algumas páginas extremamente críticas ao longo da sua obra. É certo que em La formation de l'esprit scientifique algumas referências

${ }^{11} \mathrm{Cf}$. Boaventura de Sousa SANTos, Introdução a uma ciência pós-moderna, $2^{\mathrm{a}}$ ed., Porto, Edições Afrontamento, 1990, p. 38. 
a Bacon são meramente ocasionais e não pretendem atingir o núcleo fundamental das suas propostas teóricas ${ }^{12}$. Mas há outros capítulos em que é a própria herança deste autor a ser classificada de "influência nefasta" 13 a partir da análise da forma como foram utilizadas as tábuas de presença e de ausência e da constatação de como o respectivo método terá conduzido a um "estado esclerosado dos conceitos" 14 . Quanto a Descartes, as posições de Bachelard assumem o tom de um autêntico manifesto, atravessando muitas páginas da sua obra. Em Le rationalisme appliqué é a forma de realização da dúvida na sua universalidade, que é questionada e, sobretudo, o que dela resulta: sem o recurso ao Deus criador, ao mundo destruído apenas poderia suceder um mundo fortuito, inteiramente criado pelo espírito humano, quando aquilo que o autor propõe é, entre "o mundo destruído" e o "mundo construído", "um mundo rectificado" e um "cogito", um "moi rationnel", como "consciência de rectificação"15. É esse mundo rectificado a partir de uma convicção da sua estrutura matemática que, num outro estudo datado de 1931, é expresso pela fórmula do "cogito", numa rectificação também do próprio cartesianismo, podendo, pois, dizer-se dele que "cogitatur, ergo est, entendendo-se que o facto de ser pensado matematicamente é a marca de uma existência simultaneamente orgânica e objectiva"16. Mas o texto mais significativo desta rejeição do cartesianismo é, sem dúvida alguma, o último capítulo de Le nouvel

${ }^{12}$ É o caso da sua crítica à ideia de que a diminuição da transpiração poderia ser um bom meio para prolongar a vida (cf. G. BACHELARD, La formation de l'esprit scientifique, p. 92), ou da ironia com que é referido o poder espiritual e a acção por simpatia das pedras preciosas (cf. idem, ibidem, p. 139) ou com que se faz também menção ao tratamento de uma ferida através da acção sobre a flecha que a provocou (cf. idem, ibidem, p. 147).

${ }^{13} \mathrm{Cf}$. idem, ibidem, p. 59.

${ }^{14} \mathrm{Cf}$. idem, ibidem, p. 60. Considera-se a ideia de tábua uma ideia "constitutiva do empirismo clássico", fundando "um conhecimento completamente estático, que cedo ou tarde entrava a investigação científica" (cf. idem, ibidem, p. 58). Já num estudo publicado em 1934, na Revue de Métaphysique et Morale, a sua demarcação relativamente à epistemologia baconiana era incisivamente afirmada a propósito do estudo das relações experimentais estabelecidas entre a luz e as substâncias químicas a ponto de a ciência contemporânea permitir "captar o não-baconismo da experimentação guiada pela filosofia matemática" (Cf. idem, "Lumière et substance", Revue de Métaphysique et de Morale, 41 (1934), p. 343).

${ }^{15}$ Idem, Le rationalisme appliqué, Paris, PUF, 1949, p. 51.

${ }^{16}$ Cf. idem, "Noumène et microphysique", in Études, Paris, J. Vrin, 1970, p. 18. 
esprit scientifique, intitulado precisamente "L'épistémologie non-cartésienne". Aí, depois de afirmar mais uma vez que a via da nova ciência não segue "nem os preceitos de Bacon nem os de Stuart Mill", explica-se por que razão "é necessário ir mais longe e pôr em dúvida a eficácia dos conselhos cartesianos" ${ }^{17}$. E em pouco mais de quatro dezenas de páginas são, aparentemente, algumas das grandes heranças epistemológicas do cartesianismo que são rejeitadas: o carácter redutivo do método, a busca das naturezas simples, a universalidade da dúvida, apenas para citar alguns exemplos. A essa marcha para o simples contrapõe o autor a complexidade e a relação: "na realidade, não há fenómenos simples; o fenómeno é um tecido de relações. Não há natureza simples, substância simples; a substância é uma contextura de atributos."18

Seria, no entanto, uma precipitação se reduzíssemos a relação do pensamento de Bachelard com Bacon e com Descartes às posições explicitamente assumidas nestas referências e nestes textos. Se, como é dito na obra que acabámos de citar, “o não-cartesianismo da epistemologia contemporânea não poderia fazer-nos menosprezar a importância do pensamento cartesiano, tal como o não-euclidianismo não pode fazer-nos menosprezar a organização do pensamento euclidiano"19, também a rejeição de Bacon ou de Descartes nos textos de Bachelard não pode levar-nos a ignorar algumas convergências extremamente significativas que fazem destes autores figuras representativas de determinadas dimensões comuns do projecto epistemológico da Modernidade. Aliás, uma breve passagem por alguns títulos permite-nos desde logo adivinhar a dialéctica que atravessa a sua rejeição do empirismo ou do racionalismo enquanto tais e a forma complexa como se efectua a sua superação numa nova filosofia das ciências, ditada, como bem notou Lecourt, não pelos filósofos, mas pelas exigências imanentes à própria prática científica: "Le matérialisme rationnel", "Le rationalisme appliqué", "Essai sur la connaissance approchée", "Psychanalyse de la connaissance objective" ou "L'activité rationaliste de la Physique" são expressões que permitem perceber, por um lado, que o autor francês não abandona, de modo algum, a referência à experiência empírica como fonte material e nuclear do processo do conhecimento e que,

\footnotetext{
${ }^{17}$ Idem, Le nouvel esprit scientifique, $12^{\mathrm{a}}$ ed., Paris, PUF, 1973, p. 141.

${ }^{18}$ Idem, ibidem, p. 152.

${ }^{19}$ Cf. idem, ibidem, p. 148.
} 
por outro lado, assume integralmente a dimensão racionalista do mesmo processo. Mas se se passar da superfície dos títulos para a profundidade da obra e das categorias conceptuais em que assenta, descobre-se uma convergência muito maior que a diferença de linguagem não pode levar a menosprezar: "ruptura", "instauratio" e "dúvida metódica", "obstáculos epistemológicos", "ídolos" e "noções confusas" marcam um desenho da actividade cognoscitiva que faz do método e da sua clarificação prévia a primeira afirmação do sujeito da ciência moderna e do seu poder. Por isso, a nossa proposta pressupõe uma revisitação de algumas das grandes linhas da Epistemologia de Bachelard, para, a partir daí, reler outros autores de quem ele pretende demarcar-se, com especial destaque para Francis Bacon, com o intuito de mostrar que essa demarcação não é tão radical quanto poderia parecer a uma primeira abordagem e que uma certa convergência de pontos de vista não é meramente acidental mas prende-se com alguns pressupostos do conceito de ciência que ambos os autores partilham. Uma vez reencontradas essas linhas de convergência, regressaremos de novo a Bachelard para reencontrar ainda mais alguns aspectos extremamente significativos da sua forma de pensar a produção do conhecimento científico a que alguns dos seus críticos nem sempre têm estado suficientemente atentos e que a passagem por Bacon permite reler com uma atenção renovada.

\section{Crise, ruptura, obstáculos epistemológicos e poder do sujeito na Epistemologia Histórica de Bachelard}

Falar de Bachelard foi, durante muito tempo, o mesmo que falar de ruptura epistemológica e de obstáculos epistemológicos, acentuando-se tal ligação com a reelaboração, por Althusser, dessas categorias para as aplicar a todo o trabalho teórico, e, mais especificamente, ao trabalho teórico de produção do conhecimento científico. E embora nem sempre se tenham pensado todas as implicações que uma filosofia da ruptura poderia conter, não há dúvida de que este é um tema que atravessa praticamente toda a obra do autor.

Já no seu primeiro texto, Essai sur la connaissance approchée, tese principal do seu doutoramento, se afirmava a propósito da intuição que, avançando para lá do seu domínio de origem, "esbarrava na 
penumbra das análises" podendo mesmo "tornar-se um obstáculo ao conhecimento preciso", de tal modo que "um conhecimento intuitivo é tenaz, mas fixo" e "entrava a liberdade de espírito." ${ }^{20}$ Porque afinal, como é afirmado logo nas primeiras páginas dessa obra, "a sensação que nos fere, não nos instrui" 21 , precisamente porque "o detalhe, o pitoresco e o inesperado acordam e divertem a contemplação de um espírito jovem" 22 . Mas também, já desde essa mesma obra, era dada uma configuração à intuição, à sensação e à primeira observação que obriga significativamente a constatar a sociologização do obstáculo epistemológico e, assim, a operar uma deslocação do sujeito epistémico no seu isolamento para o sujeito epistémico na sua realidade sócio-cultural: "O que é imediato para um não o é para outro. O dado é relativo à cultura, está necessariamente implicado numa construção." É a partir da consciência de que há um intermediário epistemológico que actua quer ao nível do pré-conhecimento, quer ao nível do conhecimento propriamente dito, ou seja, de que o objecto é constituído como tal através de um processo que permanentemente o reconfigura e reconfigura as suas relações ${ }^{23}$, que se pode entender a rectificação do conhecimento como um processo sobre as suas anteriores e permanentes deformações ou sobre as anteriores e permanentes deformações dos factos $^{24} \mathrm{em}$ relação dialéctica com os quais se rectifica permanentemente o sujeito ${ }^{25}$.

Seis anos depois, em Le nouvel esprit scientifique, o tema da ruptura voltará à superfície do texto bachelardiano, logo na introdução, com a

${ }^{20} \mathrm{Cf}$. idem, Essai sur la connaissance approchée, $4^{\mathrm{a}}$ ed., Paris, Vrin, 1973, p. 169.

${ }^{21}$ Idem, ibidem, p. 13.

${ }^{22}$ Idem, ibidem, p. 14.

${ }^{23}$ Idem, ibidem, p. 74: "D'abord, il ne faut pas perdre de vue que les relations des objets entre eux ne sauraient être totalement objectives; elles doivent être affectées d'un intermédiaire épistémologique."

${ }^{24}$ Idem, ibidem, p. 246: "Le fait conserve dans ces limites une manière de liberté qui nous autorise à parler de sa déformation. D'ailleurs cette déformation est très apparente dès qu'on replace le fait dans son véritable domaine, c'est-à-dire dans le monde de la perception. La connaissance consiste précisément à régler cette déformation de façon à en faire une rectification." (Sublinhado pelo autor.)

${ }^{25}$ Idem, ibidem, p. 259: "Dès qu'on veut connaître on se dispose à agir, on modifie l'objet, on modifie le sujet. La connaissance est une des figures du changement, c'est l'union de l'autre au sein du même." 
constatação de que "toda a verdade nova nasce apesar da evidência, toda a experiência nova nasce apesar da experiência imediata" ${ }^{26}$. Merece uma especial atenção neste texto a elaboração da categoria de fenomenotécnica que, prolongando ou fundamentando teoricamente a ruptura, define todo o construtivismo epistemológico de Bachelard. Tal noção havia sido introduzida num artigo publicado em 1932, na Revista Recherches Philosophiques ${ }^{27}$, para se contrapor a uma fenomenografia, formando já então um par significativo com a categoria de númeno ${ }^{28}$ que lhe permite então falar de uma metafísica que se experimenta, que se assume como uma metatécnica de uma natureza artificial, e, por isso, concluir: "A ciência atómica contemporânea é mais do que uma descrição dos fenómenos, é uma produção de fenómenos. A Física matemática é mais do que um pensamento abstracto, é um pensamento naturado." ${ }^{29}$ Esta pensée naturée, em que se pressentem ecos da Natura naturata de Espinosa, constitui uma boa expressão da dialéctica entre Fenómeno e Númeno que Le nouvel esprit scientifique aprofundará, numa clara alusão ao poder construtor do sujeito humano que "re-constrói" os fenómenos na construção do conhecimento científico e num exercício taumatúrgico do poder da razão humana: "Entre o fenómeno científico e o númeno científico, já não se trata, pois, de uma dialéctica longínqua e ociosa, mas de um movimento alternativo que, depois de algumas rectificações dos projectos, tende sempre a uma realização efectiva do númeno. A verdadeira fenomenologia científica é, pois, de forma bem essencial, uma fenomenotécnica. Ela reforça o que transparece, por detrás do que aparece, ela instrui-se pelo que constrói." E o autor conclui com uma referência lapidar ao poder criador da razão: "A razão taumaturga desenha os seus quadros sobre o esquema dos seus milagres." 30

Seria não só interessante mas extremamente importante perseguir os desenvolvimentos que posteriormente são dados a esta noção de

${ }^{26} \mathrm{Cf}$. idem, Le nouvel esprit scientifique, p. 11.

${ }^{27}$ Cf. idem, "Noumène et microphysique", Recherches Philosophiques, 1931-32, pp. 55-65, republicado em Études, Paris, J. Vrin, 1970, pp. 11-24.

${ }_{28}$ Idem, "Noumène et microphysique", in Études, p. 19: "Cette nouménologie éclaire une phénoménotechnique par laquelle des phénomènes nouveaux sont, non pas simplement trouvés, mais inventés, mais construits de toutes pièces."

${ }^{29}$ Idem, ibidem, p. 24.

${ }^{30}$ Idem, Le nouvel esprit scientifique, pp. 16-17. 
númeno e estabelecer um confronto com a sua raiz kantiana. $\mathrm{O}$ tempo não nos permite enveredar por esse caminho, mas, se não podemos deixar de concordar com Lecourt quando ele afirma taxativamente que a noção bachelardiana [de númeno] é não apenas 'não kantiana' - não conforme à noção que se designa sob o mesmo termo na Crítica da Razão Pura - mas mesmo radicalmente antikantiana"31, precisamente porque traduz a forma como a Física contemporânea, graças às matemáticas, "tem um conhecimento de objectos que escapam à intuição sensível"32, também devemos acrescentar que a própria definição da objectividade do conhecimento radica, numa acepção de inspiração kantiana, numa actividade verdadeiramente sintética, que faz com que o espírito, como se refere em Le matérialisme rationnel, seja "uma actividade de experiências ordenadas, seguindo um princípio de classificação de que ele é o mestre", de forma a não ser "vítima de aparências ilusórias, de um real que lhe foge", mas seja "consciente da sua objectividade progressiva" 33 . Aliás, tanto o próprio conceito de materialismo racional, como o de racionalismo aplicado, traduzem, no fundo, esta actividade sintetizadora do espírito científico.

Entretanto, as três obras mais significativas para uma teoria da ruptura epistemológica em Bachelard e para o esclarecimento dos diversos obstáculos epistemológicos face aos quais se exerce essa ruptura são, em primeiro lugar, La formation de l'esprit scientifique, depois La Philosophie du Non e, finalmente, Le rationalisme appliqué.

Se o "Discurso preliminar" da primeira destas três obras, se diverte, através de uma ironia anti-positivista, a traçar a lei bachelardiana dos três estados do espírito científico ("estado concreto", "estado concreto-abstracto" e "estado abstracto") e dos três estados de alma que lhe correspondem ("alma pueril ou mundana", "alma professoral" e "alma com tendência para abstrair e quintessenciar"), fá-lo fundamentalmente com o objectivo de estabelecer a ruptura entre o primeiro e o terceiro estado, pois se, num conhecimento científico depurado, "a ciência é a estética da inteligência", pode concluir-se que "a experiência científica é, então, uma experiência que contradiz a experiência

\footnotetext{
${ }^{31}$ Cf. D. LeCOURT, Bachelard ou le jour et la nuit, p. 88.

${ }^{32}$ Idem, ibidem, p. 92.

${ }^{33}$ Cf. G. Bachelard, Le matérialisme rationnel, Paris, PUF, 1953, p. 198.
} 
comum" 34 . Assim, o capítulo primeiro traçará a definição de obstáculo epistemológico, desenhando os contextos em que esta noção se torna epistemologicamente operacional, e tipificará alguns dos obstáculos mais significativos. Começando por especificar o espaço em que eles emergem e que funcionalmente os define ("é no próprio acto de conhecer, intimamente, que aparecem, por uma espécie de necessidade funcional, lentidões e perturbações" sendo "aí que descobriremos causas de inércia que chamamos obstáculos epistemológicos" ${ }^{35}$ ) a ruptura é de imediato definida nestes termos: "Com efeito, conhece-se contra um conhecimento anterior, destruindo conhecimentos mal feitos, superando o que, no próprio espírito, faz obstáculo à espiritualização"36. Neste quadro, o obstáculo é explicitamente entendido como um preconceito: "Face ao real, o que se crê saber claramente ofusca o que se deveria saber. Quando se apresenta à cultura científica, o espírito nunca é jovem. É mesmo muito velho, porque tem a idade dos seus preconceitos. ${ }^{.37} \mathrm{O}$ autor passa então a uma enumeração dos principais obstáculos, proporcionando um esquema que permite classificá-los, fundamentalmente a partir dos respectivos mecanismos da sua constituição, quer tendo em conta a forma como se experimentam os fenómenos (e que poderíamos considerar mecanismos de constituição objectiva dos obstáculos epistemológicos), quer tendo em conta a forma como os sujeito os articula e configura (e que poderíamos designar mecanismos de constituição subjectiva dos obstáculos epistemológicos). Assim, refere-se, em primeiro lugar, a experiência inicial ou a observação primeira que, com o seu luxo de imagens, suscita mais a admiração e a descrição, do que a verdadeira compreensão dos fenómenos, e a que se sucede, em segundo lugar, a tendência empirista para a generalização imediata e para a sistematização fácil. Acrescentam-se, depois, quatro outros obstáculos epistemológicos que ostentam um certo carácter antropomórfico, na medida em que conduzem a uma visão distorcida da natureza que encontra a sua raiz na percepção que se tem do comportamento humano e na sua projecção sobre os fenómenos naturais: unidade da natureza, utilidade dos fenómenos naturais,

\footnotetext{
${ }^{34}$ Idem, La formation de l'esprit scientifique, p. 10 (sublinhados do autor).

${ }^{35}$ Idem, ibidem, p. 13.

${ }^{36}$ Idem, ibidem, p. 14.

${ }^{37}$ Idem, ibidem, p. 14.
} 
substancialismo e animismo com as suas reperspectivações axiológicas da realidade. Dois outros tipos de obstáculos, também derivados da forma como o homem pode fazer delirar as coisas a partir dos seus próprios delírios, têm a ver com a linguagem, por um lado e com a libido, por outro. Os primeiros correspondem a "esta estranha inversão que pretende desenvolver um pensamento, analisando um conceito, em vez de implicar um conceito particular numa síntese racional" 38 como acontece quando "uma única imagem, ou mesmo uma só palavra constitui toda a explicação" ${ }^{39}$; os segundos mostram a influência da libido precisamente no campo do conhecimento objectivo em que ela parece ter sido recalcada, explorando Bachelard os exemplos do gérmen e da semente e da configuração sexual do seu alcance em determinadas explicações dos fenómenos empíricos ${ }^{40}$.

Em La philosophie du non prolonga-se a tonalidade das reflexões sobre o fenómeno e o númeno de Le nouvel esprit scientifique, desenvolvendo estas noções no quadro da teoria da ruptura ensaiada na obra a que acabámos de fazer referência. Dir-se-á, assim, jogando com a duplicidade do conceito de fenómeno subjacente tanto a uma fenomenologia primeira e descritiva, como a uma fenomenotécnica realizadora e construtiva, que "o númeno explica o fenómeno contradizendo-o", ou seja, "pode explicar-se o fenómeno com leis numenais que não são as leis do fenómeno" "41. Há, pois, ruptura entre o conhecimento sensível e o conhecimento científico e, por isso, esta obra continua a enumeração dos obstáculos epistemológicos directamente relacionados com o substancialismo ingénuo, com o realismo primário ou com o naturalismo imediato, como o demonstra a própria constituição da química como ciência, que vem pôr a tónica no processo inerente à construção do real na sua objectividade que é, afinal, a construção do novo "sobre-objecto" realização" e se "um real não é instrutivo e seguro senão depois de ter sido realizado e sobretudo de ter sido recolocado na sua justa

\footnotetext{
${ }^{38}$ Idem, ibidem, p. 21.

${ }^{39}$ Idem, ibidem, p. 73.

${ }^{40}$ Cf. idem, ibidem, pp. 183-209.

${ }^{41}$ Idem, La philosophie du non, Paris, PUF, 1949, p. 62.

${ }^{42}$ Idem, ibidem, p. 139.
} 
vizinhança, na sua posição de criação progressiva"43 isto significa que a superação do realismo e do substancialismo não é senão a outra face da afirmação do poder do sujeito epistémico na sua prerrogativa de criador de realidades científicas. Convém, entretanto, acrescentar que nem neste nem em outros textos do autor a descontinuidade do processo de conhecimento diz apenas respeito ao limiar de cientificidade, mas verifica-se inclusivamente dentro da ciência já constituída e, por isso, o poder criador e construtor do sujeito epistémico está numa efectivação permanente.

Na mesma linha, a obra Le rationalisme appliqué aprofundará a íntima articulação entre o materialismo técnico próprio deste "novo espírito científico" (e que não é senão a síntese de um racionalismo aplicado com um materialismo instruído) e a realidade transformada, rectificada, que tem a "marca humana por excelência, a marca do racionalismo" ". É nesse processo que assume mais uma vez uma importância nuclear a noção de obstáculo epistemológico, entendido agora de uma forma duplamente baconiana (que nunca é explicitamente assumida): por um lado, a sua classificação como ideias falsas ("juntamos à regra de enumeração das ideias justas uma regra de exorcismo explícito das ideias falsas" ${ }^{45}$ ); por outro lado, a sua recorrência, mesmo depois de superados ("se o racionalismo deve aplicar-se a um problema novo, os antigos obstáculos à cultura não tardam a manifestar-se" ${ }^{\text {"46), }}$ o que obriga o pensamento científico a um estado de "pedagogia permanente" 47 , ou, em termos mais actuais, a um estado de permanente "vigilância epistemológica", que, algumas páginas depois, implica não só uma vigilância sobre o conhecimento, mas também uma vigilância sobre o próprio método, uma vigilância da vigilância, ou até mesmo uma vigilância com a notação exponencial ${ }^{3}$, que é uma vigilância da vigilância da vigilância ${ }^{48}$, numa reassumpção explícita das exigências do Discurso do Método, traduzida como a apreensão de factos formados, factos que actualizam os princípios de informação ${ }^{49}$. Não é, pois,

\footnotetext{
${ }^{43}$ Idem, ibidem, p. 58.

${ }^{44} \mathrm{Cf}$. idem, Le rationalisme appliqué, Paris, PUF, 1949, p. 8.

${ }^{45}$ Idem, ibidem, pp. 15-16.

${ }^{46}$ Idem, ibidem, p. 15.

${ }^{47}$ Ibidem, p. 16.

${ }^{48}$ Idem, ibidem, p. 77.

${ }^{49}$ Idem, ibidem, p. 79.
} 
de admirar que, retomando mais uma vez o estilo comteano, Bachelard venha postular um quarto período, após a Antiguidade, a Idade Média e os Tempos Modernos, caracterizado precisamente pela "ruptura entre o conhecimento comum e o conhecimento científico, entre a experiência comum e a técnica científica" ${ }^{50}$, não hesitando recorrer nem à palavra "ruptura", nem à palavra "revolução" e dedicando ao tema todo um capítulo desta obra. Sugestivo, para o que nos interessa neste percurso, é a consideração das trajectórias que permitem separar os isótopos no espectroscópio de massa como "teoremas reificados", realizando o conhecimento científico, numa significativa alusão à influência de Brunschwicg e a uma certa inspiração espinosista, um percurso de desdobramento idêntico ao que étraduzido pela expressão dupla "natura naturans" e "natura naturata" ${ }^{1}$. Segue-se a enumeração de alguns dos tipos mais significativos de obstáculos epistemológicos, como a percepção axiológica do real ${ }^{52}$, o utilitarismo ${ }^{53}$, a tendência para a generalização ou para a particularização ${ }^{54}$, ou o primado do sensível e da sensação $0^{55}$.

Poderíamos continuar a perseguir esta teoria da ruptura e dos obstáculos epistemológicos em todos os outros escritos do autor, mas o tempo não o permite e penso serem suficientes as referências feitas para ilustrar a nossa tese fundamental: $1^{\mathrm{a}}$ a teoria da ruptura é, antes de mais, uma reescrita da fundação da cientificidade que os vários tratados do método abordaram a seu modo no princípio da Modernidade; $2^{a}$ por essa inscrição metodológica ela significa imediatamente a afirmação do poder do sujeito epistémico no que lhe é mais directamente acessível: o conhecimento, o discurso e o real científico; 3) é a partir desse poder do sujeito epistémico que pode ser entendido o poder que daí resulta para o homem de ciência, ou seja o seu poder sobre o mundo.

\footnotetext{
${ }^{50}$ Cf. idem, ibidem, p. 103.

${ }^{51} \mathrm{Cf}$. idem, ibidem, p. 10.

${ }^{52}$ Cf. idem, ibidem, p. 111.

${ }^{53} \mathrm{Cf}$. idem, ibidem.

${ }^{54} \mathrm{Cf}$. idem, ibidem, p. 112.

${ }^{55}$ Cf. idem, ibidem, pp. 113-117.
} 


\section{Crise, Instauratio, idola e poder da ciência em F. Bacon}

Em 1620, três anos antes de Galileu dar à estampa o seu Il saggiatore e dezassete anos antes de Descartes publicar o Discours de la Méthode, é impresso um livro que, pelo carácter enciclopédico e programático que anuncia, toma como título a expressão instauratio magna, que deveria constar de seis partes e de que se publica então a segunda parte intitulada Novum Organon ou Aforismos sobre a interpretação da natureza e o reino do homem. Inserindo-se o projecto numa perspectiva religiosa e milenarista (tratava-se de restaurar o saber e o poder de que Adão havia gozado no Paraíso ${ }^{56}$ ), a intenção de Bacon era efectivamente uma refundação total da ciência e da investigação científica o que pressupunha obviamente a teorização da ruptura que havia que estabelecer com o saber herdado e com caducas e estéreis metodologias e, por isso, o interesse desta obra ultrapassa em muito a mera teorização da indução com a célebre teoria das tábuas, merecendo-nos especial atenção a sua crítica aos obstáculos que dificultam a correcta interpretação da natureza, ou seja, às antecipações da natureza, condensada na sua teoria dos idola.

Para a forma como o interesse por esta teoria pode ajudar a desconstruir o mito elaborado ao longo do iluminismo de um Bacon radicalmente empirista e indutivista já alguns autores têm chamado a atenção. É assim que Gadamer, embora, com a sua reabilitação do preconceito $^{57}$, acabe por descobrir nessas ideias prévias virtualidades que Bacon não imaginava, dedica a esta teoria alguns parágrafos bem elucidativos de Wahrheit und Methode, precisamente no último capítulo com que encerra a secção em que dedicou um outro capítulo aos preconceitos como condição da compreensão $0^{58}$, considerando que "a teoria baconiana dos 'preconceitos' tem o sentido de tornar simplesmente possível um emprego metódico da razão" 59 , motivo pelo

${ }^{56}$ Cf. Miguel Angel Granada, "Prólogo" a Francis Bacon - La gran restauración, Madrid, Alianza Editorial, 1985, pp. 7-11.

${ }^{57}$ Cf., a este propósito, Maria Luísa P. F. Silva, O preconceito em H.-G. GADAMER. Sentido de uma reabilitação, Lisboa, JNICT/F. C. Gulbenkian, 1995.

${ }^{58}$ Cf. H.-G. Gadamer, Hermeneutik. I. Wahrheit und Methode. Grundzüge einer philosophischen Hermeneutik, $5^{\text {a }}$ ed., Tübingen, J, C. B. Mohr (Paul Siebeck), 1986, pp. 281-295.

${ }^{59}$ Idem, ibidem, p. 355. 
qual faz dela o seu verdadeiro contributo para a Ciência Moderna ${ }^{60}$. $\mathrm{E}$, antes de Gadamer, numa perspectiva ligeiramente diferente, também Karl Mannheim, os aproximou do conceito de ideologia ${ }^{61}$, e sublinhou o seu alcance sociológico ${ }^{62}$. E ainda há bem pouco tempo, um dos mais recentes tradutores do Novum organon para alemão ${ }^{63}$, caracterizando a obra de Bacon como uma filosofia da investigação e do progresso ${ }^{64}$, em que, inclusivamente, se poderia descobrir o gérmen de uma "sociologia do saber" 65 , afirmava incisivamente que "todo o desenvolvimento da sociedade moderna está presente na filosofia de Bacon" 66 .

A teoria dos Idola é recorrente praticamente em toda a obra de Bacon. Delineada já no Temporis partus masculus, redigida seguramente antes de 1603, e presente no Valerius terminus, de 1603, e no Advancement of Learning, de 1605, ela apresenta-se com grande desenvolvimento tanto no Novum organon, como no De augmentis, merecendo também algumas alusões significativas na "Distributio operis" da Instauratio magna. Tendo, todavia, em conta o carácter de síntese que esta reflexão comporta, não são as diferenças, significativas mas não muito acentuadas, entre umas obras e outras que nos interessam, mas sim o significado global desta teoria e a forma como ela pode contribuir para lançar uma nova luz sobre a actualidade do seu autor que permita rectificar (para utilizarmos um termo tanto do chanceler inglês como do

${ }^{60}$ Idem, ibidem, p. 355: "Seine eigentliche Leistung liegt vielmehr darin, daß er die Vorurteile, die den menschlichen Geist besetzt halten und von der wahren Erkenntnis der Dinge abführen, umfassend untersucht und damit eine methodische Selbstreinigung des Geistes vollbringt, die mehr eine disciplina als eine Methodik darstellt."

${ }^{61} \mathrm{~K}$. Mannheim, Ideology and Utopie. An Introduction to the Sociology of Knowledge, London, Routledge and Kegan Paul, 1976, p. 55.: "'According to this interpretation, Bacon's theory of the idola may be regarded to a certain extent as a forerunner of the modern conception of ideology."

${ }^{62}$ Idem, ibidem: "Furthermore, the realization that society and tradition may become sources of error is a direct anticipation of the sociological point of view."

${ }^{63}$ Cf. Francis BACON, Neues Organon. Lateinisch-Deutsch, Hrsg. u. m. einer Einl. von W. Krohn, Darmstadt, Wissenschaftliche Buchgesellschaft, 1990.

${ }^{64}$ Cf. W. Krohn, "Francis Bacon, Philosophie der Forschung und des Fortschritts", in: L. Kreimendhahl (Hrsg.), Philosophen des 17. Jahrhunderts. Eine Einführung, Darmstadt, Wissenschaftliche Buchgesellschaft, 1999, pp. 23-45.

${ }^{65} \mathrm{Cf}$. idem, ibidem, pp. 32-34.

${ }^{66}$ Idem, ibidem, p. 23. 
filósofo francês) o excessivo empirismo com que é precipitadamente etiquetado e arrumado na prateleira das classificações fáceis e redutoras.

A consciência de que Bacon parte é, indubitavelmente, a consciência da necessidade de uma ruptura, mas uma ruptura radical ${ }^{67}$ : não se trata de substituir as velhas filosofias por uma nova filosofia que se mova sobre o mesmo terreno, mas sim de partir de uma nova atitude do homem perante a natureza que, implicando princípios diferentes e diferentes argumentos, implica obviamente uma nova atitude perante o saber ${ }^{68}$. Basta olhar para os primeiros parágrafos dos Cogitata et visa, de 1607, ou para o Prefácio da Instauratio magna, para nos apercebermos de que a instauração da ciência postula, mais do que uma lógica do silogismo, uma lógica dos factos ou dos efeitos, pois é por eles que se mede o alcance do saber. A ciência baconiana é já, antecipando o projecto bachelardiano, profundamente realizadora e é por esse objectivo que se define nas primeiras páginas da Instauratio: "O fim que esta nossa ciência se propõe é a descoberta não de argumentos, mas de artes; não de coisas conforme aos princípios, mas dos próprios princípios, não de razões prováveis, mas de designações e indicações para a acção." E acrescenta: "Desta maneira, à diversa intenção segue-se um efeito diverso. Pois ali vence-se e encadeia-se o adversário na disputa, aqui a natureza na acção." ${ }^{69}$ Estabelecido este objectivo para a ciência e feita a demarcação da ciência anterior, Bacon avança com o primeiro passo indispensável para a construção do novo saber, "a preparação do uso metódico da razão" que passa, em primeiro lugar, por uma identificação da fonte, do lugar e da natureza dos principais obstáculos epistemológicos, para que, em segundo lugar, se possa operar a consequente ruptura. E é precisamente em termos de obstáculos que os

${ }^{67} \mathrm{~F}$. BACON, Instauratio magna, Collected and Edited by James Sedding, Robert Leslie Ellis and Douglas Denon Heath. Vol. I, Friedrich Fromman Verlag Günther Holzboog, Stuttgart-Bad Cannstatt, 1963 (Reprodução da edição de Londres de 1858), pp. 119-145, p. 121: "Restabat illud unum ut res de integro tentetur melioribus praesidiis, utque fiat scientiarum et artium atque omnis humanae doctrinae in universum Instauratio, a debitis excitata fundamentis." Citaremos as obras de Bacon a partir desta edição, com a abrevatura Sp., seguida da indicação do respectivo volume.

${ }^{68}$ Cf. Paolo Rossi, Francis Bacon: de la magia a la ciencia, trad. castelhana de Susana Gómez López, Madrid, Alianza Editorial, 1990, p. 102.

${ }^{69}$ F. B ACON, Instauratio magna, "Distributio operis", Sp. I, pp. 135-136. 
Cogitata et visa referenciam a opinião e o senso-comum: "Encontramos também na opinião e no senso-comum dos homens muito do que impede o livre acesso a novas descobertas nas ciências", pelo que "os obstáculos [impedimenta] ao aperfeiçoamento das ciências são não apenas exteriores e adventícios mas são inatos e têm a sua fonte nos sentimentos dos homens" "as palavras que são, por assim dizer, as medalhas que representam a imagem e a dominação do vulgar"71. Também a humana configuração dos dados dos sentidos nos engana, dado que, como se dirá na Instauratio magna, ela é feita à imagem do homem e não da natureza, "ex analogia hominis, non ex analogia universi", sendo, por isso, necessário um contínuo trabalho de rectificação (antes de Bachelard, a palavra é de Bacon $^{72}$ ) mediante o recurso a instrumentos e a experiências (a uma fenomenotécnica, diria Bachelard), para que o sentido captado não seja o sentido aparente mas o sentido profundo da coisa de que o homem de ciência é ministro e intérprete ${ }^{73}$.

Para compreender o alcance da crítica baconiana aos "ídolos" (ou seja, às "antecipações da natureza") na sua articulação com a teoria da indução como concretização da via para a "interpretação da

${ }^{70}$ Idem, Cogitata et visa, Sp. III, pp. 598 e 599: "Cogitavit et illud; etiam in opinione hominum et sensi communi, multa ubique occurrere quae novas scientiarum accessiones libero aditu prohibeant. [...] Visum est ei itaque, impedimenta melioris scientiarum status non tantum externa et adventitia, sed et innata et ex ipsis sensibus hausta esse."

${ }^{71}$ Idem, ibidem, p. 599: "Verba enim certe tanquam numismata esse, quae vulgi imaginem et principiatum repraesentent."

${ }^{72}$ Idem, Instauratio magna, "Distributio operis", Sp. I, p. 138: "Itaque, ut his occurratur, nos multo et fido ministerio auxilia sensui undique conquisivimus et contraximus, ut destitutionibus substitutiones, variationibus rectificationes suppeditentur. Neque id molimur tam instrumentis quam experimentis." Veja-se também o aforismo 69 da $1^{\text {a }}$ parte (Sp. I, p. 179): "Primo, impressiones sensus ispius vitiosae sunt; sensus enim et destituit et fallit. At destitutionibus substitutiones, fallaciis rectificationes debentur."

${ }^{73}$ Idem, ibidem, Sp. I, pp. 138-139: "Itaque perceptioni sensus immediatae ac propriae non multum tribuimus: sed eo rem deducimus, ut sensus tantum de experimento, experimentum de re iudicet. Quare existimammus nos sensus (a quo omnia in naturalibus petenda sunt, nisi forte libeat insanire) antistites religiosos et oraculorum eius non imperitos interpretes, nos praestitisse." 
natureza"74 é necessário integrá-la na quadripartida divisão da lógica em arte da investigação ou da invenção, arte do exame ou do juízo, arte da conservação ou da memória e arte da elocução ou da comunicação, onde pesam as influências de Pedro Ramus, com uma diferença significativa: é que enquanto em Pedro Ramus a arte da invenção se restringia à ordenação do material para obter a adesão dos ouvintes, estando assim vinculada, por um lado, à retórica e, por outro lado, à tópica, em Bacon, com a distinção entre invenção dos argumentos e invenção das artes e das ciências, redescobre-se um sentido radical para o inventar e recoloca-se a ciência no âmbito da sua ligação à acção, numa indissociabilidade entre artes mecânicas e liberais e invenção de axiomas ${ }^{75}$. Por sua vez, a arte do juízo, habilitando a julgar o que já foi inventado, comporta, para além de uma dimensão confirmativa, uma dimensão refutativa, que a retórica clássica traduzia com o termo reprehensio ou confutatio e que Cícero designava com o termo redargutio, que o Chanceler adopta para título de um texto escrito em $1608^{76}$ e que, por sinal, constitui uma das primeiras tentativas de análise do saber e da filosofia anterior em termos sociológicos ${ }^{77}$.

Os ídolos têm de ser vistos, pois, antes de mais, como obstáculos, que sustentam o senso comum a que Bacon também chama "consenso geral"78 e que dificultam a instauração da via justa para o conhecimento

${ }^{74}$ Veja-se o aforismo 26 da I Parte do Novum Organon (Sp. I, p. 161): "Rationem humanam qua utimur ad naturam, Anticipationes Naturae (quia res temeraria est et prematura), at illam rationem quae debitis modis elicitur a rebus, Interpretationem Naturae, docendi gratia vocare consuevimus." (Sublinhados do autor).

${ }^{75}$ Cf. idem, De augmentis, Sp. I, p. 617.

${ }^{76} \mathrm{Cf}$. idem, Redargutio philosophiarum, Sp. III, 557-587.

${ }^{77} \mathrm{Cf}$. W. Krohn, "Francis Bacon, Philosophie der Forschung und des Fortschritts", p. 33: "In einer kleinen Schriften 'Redargutio philosophiarum' (Wiederlegung der Philosophien) von 1608 vertritt er zum ersten Mal die Ansicht, daß man Philosophien nicht einfach direkt auf ihre Richtigkeit prüfen kann, sondern ihre Beurteilung von 'Zeichen' abhängig machen muß. Solche Zeichen geben gleichsam extern Auskunft über eine Philosophie und sollen befähigen, nicht über ihre Wahrheit, sondern über ihre Angemessenheit oder Eignung für eine bestimmte Problemlage, Zielvorstellung und kulturelle Einbindung zu urteilen."

${ }^{78} \mathrm{Idem}$, ibidem, $1^{\mathrm{a}}$ P., aforismo 27, Sp. I, p. 161: "Anticipationes satis firmae sunt ad consensum". E no aforismo 29 as antecipações e os respectivos obstáculos pré-bachelardianamente identificados com a opinião, são considerados na sua orientação para o domínio do assentimento e não das coisas (Sp. I, p. 161): 
científico, e é nesses termos que deve ser lida a referência introdutória que lhes é feita no aforismo 38, mostrando, em primeiro lugar, a resistência que oferecem à via da verdade e, em segundo lugar, o seu carácter recorrente que exige, em mais uma notável antecipação ao epistemólogo francês, uma vigilância permanente: "Os ídolos e as noções falsas que já se apoderaram do entendimento humano e se fixaram nele muito profundamente, não só assediaram as mentes de tal forma que se torna difícil o acesso à verdade; mas também, uma vez esse acesso aberto e franqueado, eles acorrerão novamente na própria restauração das ciências e serão nocivos, a não ser que, estando os homens prevenidos, deles se protejam na medida do possível." ${ }^{79}$

Entretanto, se Bachelard procederá séculos depois a uma classificação dos obstáculos epistemológicos a partir dos respectivos mecanismos, objectivos e subjectivos, de constituição, Bacon procederá também à sua classificação dos ídolos, tendo fundamentalmente em conta a sua fonte ou origem: "São de quatro géneros os ídolos que assediam a mente humana. No sentido de uma maior clareza, demos-lhes nomes distintos: chamaremos ao primeiro género Ídolos da Tribo, ao segundo género Ídolos da Caverna, ao terceiro género Ídolos do Foro e ao quarto género Ídolos do Teatro." ${ }^{80}$ Correspondem estas designações, como é sabido, às fontes de que provêm tais obstáculos ao conhecimento: os primeiros radicam na compleição da natureza humana e correspondem àquilo que poderíamos caracterizar como obstáculos antropomórficos, uma vez que asssentam na transposição da medida do homem para todo o universo, ou seja, misturam a própria natureza humana com a natureza das coisas (estando muito próximos dos obstáculos

"In scientiis quae in opinionibus et placitis fundatae sunt, bonus est usus anticipationum et Dialecticae; quando opus est assensum subjugare, non res."

${ }^{79}$ Idem, ibidem, $1^{\text {a }}$ parte, aforismo 38, Spedding, I, p. 163: "Idola et notiones falsae quae intellectum humanum iam occuparunt atque in eo haerent, non solum mentes hominum ita obsident ut veritati aditus difficilis pateat; sed etiam dato et concesso aditu, illa rursus in ipsa instauratione scientiarum occurrent et molesta erunt, nisi homines praemoniti adversus ea se quantum fieri potest muniant."

${ }^{80}$ Idem, ibidem, $1^{\text {a }}$ P., aforismo 39, Sp. I, p. 163: "Quattuor sunt genera Idolorum quae mentes humanas obsident. Iis (docendi gratia) nomina imposuimus; ut primum genus, Idola tribus; secundum, Idola specus; tertium, Idola Fori; quartum, idola Theatri vocentur." 
bachelardianos como o utilitarismo ${ }^{81}$, a visão axiológica do real ${ }^{82}$, o animismo finalista ${ }^{83}$ ou o primado da intuição sensível no seu colorido imediato e natural $\left.{ }^{84}\right)$; os segundos dizem mais respeito à compleição de cada um e correspondem aos obstáculos que têm a ver com o peso da educação, da formação e da prática já havida no contacto com as coisas (podendo ser comparados com as primeiras generalizações de Bachelard ou com a força impressiva das primeiras experiências ${ }^{85}$ ), e também com a tendência para o estudo do pormenor ou a tendência para centrar a atenção no genérico e no universal ${ }^{86}$; os terceiros radicam na natureza comunicativa dos homens, no comércio que têm uns com os outros, sobretudo através da linguagem, mais ligada à percepção do senso comum do que à investigação científica ${ }^{87}$ (sendo tão incontornável a comparação com o obstáculos verbais de Bachelard, que os pressupostos subjacentes à crítica de Bacon aos ídolos correspondentes a nomes de coisas que existem mas que são confusos e mal definidos

${ }^{81} \mathrm{Cf}$. idem, ibidem, $1^{\text {a }}$ P., aforismo 46 e a tendência para valorizar as instâncias positivas e agradáveis e desvalorizar as negativas e desagradáveis (Sp. I, p. 166).

${ }^{82} \mathrm{Cf}$. idem, ibidem, $1^{\text {a }} \mathrm{P}$., aforismo 45 , que radica a ideia do movimento circular dos astros na perfeição do círculo (Sp. I, p. 165).

${ }^{83} \mathrm{Cf}$. idem, ibidem, $1^{\mathrm{a}} \mathrm{P}$., aforismo 48 e a sua crítica às causas finais, mais próprias da natureza do homem do que da natureza do universo (Sp. I, p. 167).

${ }^{84} \mathrm{Cf}$. idem, ibidem, $1^{\text {a }} \mathrm{P}$., aforismo 50 e a crítica à falácia dos sentidos, mais expostos ao que os afecta imediatamente (Sp. I, p. 168).

${ }^{85} \mathrm{Cf}$. idem, ibidem, $1^{\mathrm{a}} \mathrm{P}$., aforismo 54 e a crítica à tentação das primeiras generalizações de Aristóteles ou de W. Gilbert (Sp. I, p. 169).

${ }^{86} \mathrm{Cf}$. idem, ibidem, $1{ }^{\text {a }} \mathrm{P}$., aforismo 55 e a crítica à unilateralidade e aos excessos da visão analítica e singularizante e da visão comparativa e universalizante (Sp. I, p. 169) ou o aforismo 57 e a crítica à unilateralidade e aos excessos da visão redutora e simplificadora e da visão articuladora e sistematizadora (Sp. I, p. 170). Veja-se também, a este propósito, a afirmação de BACHELARD em La formation de l'esprit scientifique (p.60), que quase repete o sentido destes aforismos de Bacon: "Comme nous le disions dans notre premier chapître, l'esprit scientifique peut se fourvoyer en suivant deux tendances contraires: l'attrait du singulier et l'attrait de l'universel. $\mathrm{Au}$ niveau de la conceptualisation, nous définirons ces deux tendances comme caractéristiques d'une connaissance en compréhension et d'une connaissance en extension." Curiosamente, esta afirmação segue-se imediatamente a uma secção do mesmo capítulo em que o autor, na sequência de Liebig, desenvolve uma incisiva "condenação do baconismo" (Cf. BACHELARD, La formation de l'esprit scientifique, pp. 58-60).

${ }^{87}$ Cf. F. BACON, Novum organon, $1^{\text {a }}$ P., aforismo 59 (Sp. I, pp. 170-171). 
- como é exemplificado com a palavra húmido ${ }^{88}$ - são precisamente os mesmos que estão subjacentes à crítica de Bachelard ao pretenso poder explicativo da carga imagética de determinadas palavras - como é também exemplificado com a palavra esponja ${ }^{89}$ ); finalmente, os últimos têm a ver com escolas ou correntes filosóficas que criam verdadeiros cenários que se sobrepõem à realidade, sendo especialmente criticados os sofístico-racionais, que abandonam rapidamente a experiência e quase tudo fazem depender da meditação do seu espírito, os empiristas, que generalizam demasiado rapidamente a partir de poucas experiências realizadas, e os supersticiosos, que misturam considerações de natureza religiosa e teológica com considerações de natureza científica (sendo possível associar esta crítica, tipificada na discussão com Aristótele ${ }^{90} \mathrm{ou}$ com os químicos ${ }^{91}$, à crítica de Bachelard ao obstáculo substancialista ${ }^{92}$ ou à generalização apressada ${ }^{93}, \mathrm{e}$, nos moldes em que é feita em alguns textos, como a Redargutio philosophiarum, à crítica aos obstáculos ideológicos presente na reformulação althusseriana da ruptura epistemológica). O aforismo 69 sintetiza em quatro aspectos o carácter obstacular dos ídolos, referindo-os ao carácter vicioso dos sentidos, à abstracção incorrecta das suas impressões, à indução incorrecta que universaliza apressadamente e à inteira subjugação da experiência às ideias previamente feitas pela razão ${ }^{94}$.

Esta convergência metodológica e epistemológica entre o princípio e o fim da Modernidade pouco significado teria, no entanto, se não permi-

\footnotetext{
${ }^{88} \mathrm{Cf}$. idem, ibidem, $1^{\text {a }}$ P., aforismo 60 (Sp. I, pp. 171-172)

${ }^{89} \mathrm{Cf}$. BACHELARD, La formation de l'esprit scientifique, p. 73 e ss.

${ }^{90}$ Cf. F. BACON, Novum organon, $1^{\text {a }}$ P., aforismo 63 (Sp. I, pp. 173-174).

${ }^{91}$ Cf. idem, ibidem, $1{ }^{\text {a }}$ P., aforismo 64 (Sp. I, pp. 174-175).

${ }^{92} \mathrm{Cf}$. BACHELARD, La formation de l'esprit scientifique, pp. 97-129.

${ }^{93}$ Cf. idem, ibidem, pp. 55-72.

${ }^{94}$ F. BACON, Novum organon, $1^{\text {a }}$ P., aforismo 69 (Sp. I, p. 179): “Qui quidem processus quadruplex est, et vitia ejus totidem. Primo, impressiones sensus ipsius vitiosae sunt; sensus enim et destitutit et fallit. At destitutionibus substitutiones, fallaciis rectificationes debentur. Secundo, notiones ab impressionibus sensuum male abstrahuntur, et interminatae et confusae sunt, quas terminatas et bene finitas esse oportuit. Tertio, inductio mala est, quae per enumerationem simplicem principia concludit scientiarum, non adhibitis exclusionibus et solutionibus, sive separationibus naturae debitis. Postremo, modus ille inveniendi et probandi, ut primo principia maxime generalia constituantur, deinde media axiomata ad ea applicentur et probentur, errorum mater est et scientiarum omnium calamitas."
} 
tisse descortinar uma outra convergência que, essa sim, se prende, afinal, com um dos traços definidores da Ciência Moderna: a redefinição do estatuto da verdade científica a partir da redefinição do sujeito epistémico no horizonte da afirmação do poder da ciência. Se a parte destrutiva do Novum organon tem como função polir o espelho do entendimento para que melhor represente a natureza das coisas ${ }^{95}$, seria um erro interpretar a analogia do espelho em termos de um radical empirismo. Embora a purificação do entendimento não conduza, como em Descartes, a uma reconstrução do objecto e do mundo dos objectos pela "re-figuração" das "naturezas simples" que se segue à sua "desconstrução eidética" 96 , o poder que se reconhece à ciência é já indissociável do reconhecimento do poder do próprio entendimento, razão pela qual se deve interpretar o projecto epistemológico de Bacon como a procura de um equilíbrio entre o poder da experiência e o poder da mente, equilíbrio esse que é afirmado metaforicamente no primado da abelha, imagem em que cabe "o verdadeiro trabalho da filosofia" que deve assentar "numa aliança estreita entre a faculdade experimental e a faculdade racional" à qual o autor não hesita chamar "matrimónio verdadeiro e legítimo"98.

${ }^{95} \mathrm{Cf}$. idem, ibidem, $1^{\text {a }}$ P., aforismo 41 (Sp. I, p. 164): "Estque intellectus humanus instar speculi inaequalis ad radios rerum, qui suam naturam naturae rerum immiscet, eamque distorquet et inficit."

${ }^{96} \mathrm{Cf}$., a este propósito, toda a regra XII que permite concluir como as "naturezas simples" de Descartes não são o reencontro da simplicidade das coisas em si, mas o ponto de partida do intuitus mentis, do olhar intelectivo, para a reconstrução do mundo sob o prisma da ordem, da proporção e da medida (base da nova mathesis). Para uma interpretação de toda esta regra, cf. J.-L. MARION, Sur l'ontologie grise de Descartes, $2^{\mathrm{a}}$ ed., Paris, Vrin, 1993, pp. 113-148. Aqui se diz (p. 137) que "l'intuitus ne connaît pas seulement les choses comme ses objets, mais produit encore ses objets comme un monde", acrescentando-se algumas páginas depois (p. 141) que "ce que la connaissance connaît et reconnaît comme son objet, ce n'est jamais la chose même, mais le substitut qu'en construisent les natures simples."

${ }^{97}$ F. BACON, Novum organon, P. I, aforismo 95 (Sp. I, p. 201): "Neque absimile philosophiae verum opificium est; quod nec mentis viribus tantum aut praecipue nititur, neque ex historia naturali et mechanicis experimentis praebitam materiam, in memoria integram, sed in intellectu mutatam et subactam reponit. Itaque ex harum facultatum (experimentalis scilicet et rationalis) arctiore et sanctiore foedere (quod adhuc factum non est) bene sperandum est."

${ }^{98}$ Idem, Instauratio magna,"Praefatio" (Sp., I, p. 131): “Atque hoc modo inter empiricam et rationalem facultatem (quarum morosa et inauspicata divortia et repudia omnia in humana familia turbavere) conjugium verum et legitimum in perpetuum nos firmasse existimamus." 
Aliás, uma cuidadosa leitura da sua teoria da "interpretação da natureza", cuja chave é "a legítima e verdadeira indução" "99, permite-nos ver no recurso às célebres tábuas descritas nos aforismos 11 a 16 da $2^{\text {a }}$ parte do Novum Organon, não o momento fundamental do método, ou o processo que suporia o espírito humano como uma mera tábua rasa, mas sim uma ajuda para a memória, a fim de que a mente, essa espécie de "fogo divino que faz a solução e a separação da natureza" ${ }^{100}$, mais facilmente possa inventar as formas e as naturezas dos corpos (e inventar significa aqui algo mais do que descobrir ou encontrar, pois o modelo para a inventio baconiana não é a inventio dos argumentos mas a inventio das artes e o progresso científico só se conseguirá se se transpuser a dinâmica inventiva das artes para a própria ciência $\left.{ }^{101}\right)$. É especialmente importante neste contexto verificar que as formas cuja "investigação" a indução realiza não são propriamente as formas aristotélicas, mas sim as leis constitutivas de um fenómeno empírico num determinado corpo ou num determinado tipo de corpos: "Efectivamente, quando falamos de formas, queremos apenas dizer leis e determinações do acto puro que governam e estabelecem uma natureza simples, como o calor, a luz, o peso, em toda a espécie de matéria ou coisa capaz de a receber; assim,

\footnotetext{
${ }^{99}$ Idem, Novum organon, P. II, aforismo 10 (Sp. I, p. 236): "Itaque tertio, adhibenda est Inductio legitima et vera, quae ipsa clavis est Interpretationis."

${ }^{100}$ Idem, ibidem, P. II, aforismo 16 (Sp. I, p. 257): "Itaque naturae facienda est proursus solutio et separatio, non per ignem certe, sed per mentem, tanquam ignem divinum."

${ }^{101} \mathrm{Cf}$., a este propósito as páginas de abertura do "Prefácio" à Instauratio magna em que se compara a esterilidade da ciência e da filosofia com os progressos conseguidos pelas artes nos tempos mais recentes (Sp. I, p. 126): "In artibus autem mechanicis contrarium evenire videmus; quae ac si aurae cujusdam vitalis forent participes, quotidie crescunt et perficiuntur, et in primis authoribus rudes plerunque et fere onerosae et informes apparent, postea vero novas virtutes et commoditatem quandam adipiscuntur, eo usque, ut citius studia hominum et cupiditates deficient et mutentur, quam illae ad culmen et perfectionem suam pervenirent. Philosophia contra et scientiae intellectuales, statuarum more, adorantur et celebrantur, sed non promoventur." Não admira, pois, que na "Distributio operis", logo a seguir (Sp I, pp. 135-136) se afirme taxativamente: "Nam huic nostrae scientiae finis proponitur, ut inveniantur non argumenta sed artes, nec principiis consentanea sed ipsa principia, nec rationes probabiles sed designationes et indicationes Operum."
} 
é uma só coisa a forma do calor ou a forma da luz e a lei do calor ou a lei da luz." 102

Com isto é justamente o estatuto epistémico da verdade científica e do seu sujeito que são reformulados, porque é a verdade que assim surge articulada com a sua eficácia. Di-lo o aforismo I que abre a $2^{\mathrm{a}}$ parte, ao cruzar o objectivo do poder humano ("introduzir num dado corpo uma ou várias naturezas novas") com a finalidade da ciência humana ("inventar a forma ou a diferença verdadeira de uma dada natureza ou a natureza naturante ou a fonte da emanação" 103 ), tal como já o havia dito, na $1^{\text {a }}$ parte, tanto o primeiro aforismo ao ligar o humano "facere" ao humano "intelligere" da natureza ${ }^{104}$, como o terceiro aforismo, ao estabelecer: "A ciência e a potência humana coincidem no mesmo, porque a ignorância da causa priva do efeito. Na verdade, não é possível vencê-la senão obedecendo-lhe, e o que na contemplação tem o valor de causa, tem na operação o valor de regra." 105 Trata-se de uma recuperação científica da eficácia da magia ${ }^{106}$ e Bacon, ao privilegiar a

${ }^{102}$ Idem, Novum Organon, P. II, aforismo 17 (Sp. I, pp. 257-258): “Nos enim quum de Formis loquimur, nil aliud intelligimus quam leges illas et determinationes actus puri, quae naturam aliquam simplicem ordinant et constituunt; ut calorem, lumen, pondus; in omnimoda materia et subjecto susceptibili. Itaque eadem res est Forma Calidi aut Forma Luminis, et Lex Calidi sive Lex Luminis."

${ }^{103}$ Idem, ibidem, P. II, aforismo 1 (Sp. I, p. 227): "Super datum corpus novam naturam sive novas naturas generare et superinducere, opus et intentio est humanae Potentiae. Datae autem naturae Fomam, sive differentiam veram, sive naturam naturantem, sive fontem emanationis (ista enim vocabula habemus quae ad indicationem rei proxime accedunt) invenire, opus et intentio est humanae Scientiae)."

${ }^{104}$ Idem, ibidem, P. I, aforismo 1 (Sp. I, p. 157): "Homo, Naturae minister et interpres, tantum facit et intelligit quantum de Naturae ordine re vel mente observaverit, nec amplius scit aut potest."

${ }^{105}$ Idem, ibidem, P.I, aforismo 3 (Sp. I, p. 157): "Scientia et potentia humana in idem coincidunt, quia ignoratio causae destituit effectum. Natura enim non nisi parendo vincitur; et quod in contemplatione instar causae est, id in operatione instar regulae est."

${ }^{106}$ Idem, ibidem, P. II, Aforismo 9 (Sp. I, p. 235): "Videlicet, ut inquisitio Formarum, quae sunt (ratione certe et sua lege) aeternae et immobiles, constituat Metaphysicam; inquisitio vero Efficientis, et Materiae, et Latentis Processus, et Latentis Schematismi (quae omnia cursum naturae communem et ordinarium, non leges fundamentales et aeternas respiciunt) constituat Physicam: atque his subordinentur similiter practicae duae; Phisicae Mechanica; Metaphysicae (perpurgato nomine) Magia, propter latas ejus vias et maius imperium in naturam." 
invenção das formas como via de acesso aos efeitos ${ }^{107}$, postula assim uma concepção de ciência e de verdade científica prioritariamente operadora e realizadora, constituindo-se, a seu modo, como mais um marco na definição da verdade a partir do respectivo construto mecânico, segundo o qual o conhecimento verdadeiro de algo depende da capacidade e da potência de o homem o fazer, o construir ou reconstruir de acordo com o seu projecto e dominando a necessidade das suas leis e das suas causas ${ }^{108}$. Por isso, numa certa antecipação ao "verum ipsum factum" de Vico ${ }^{109}$ e à afirmação da dinâmica realizadora da ciência de Bachelard, também Bacon identificará a percepção da verdade com a produção dos resultados da sua efectivação, estabelecendo, após sublinhar mais uma vez a distinção entre os ídolos do espírito humano e as ideias do espírito divino, a implicação intrínseca entre verdade e utilidade: "É por isso que as coisas consideradas em si próprias são, neste género, verdade e utilidade e as próprias operações devem ser mais estimadas pelo seu carácter de prendas de verdade do que pelas comodidades que proporcionam à vida." 110 Isto não significa uma concepção utilitarista de verdade ou a redução da verdade à sua utilidade humana, mas sim, como bem reconheceu e sustentou Paolo Rossi, o reconhecimento da indissociabilidade, no que se refere às próprias coisas consideradas em

Sobre articulação entre ciência e magia no pensamento de Bacon, veja-se a já antiga mas excelente monografia de Paolo ROSSI, Francis Bacon, de la magia a la ciencia, já anteriormente citada.

${ }^{107}$ Cf., a este propósito, António Pérez-Ramos, “Bacon's Forms and maker's knowledge tradition", in: Markku Peltonen (Ed.) - The Cambridge Companion to Bacon, Cambridge, Cambridge University Press, 1996, pp. 99-120.

${ }^{108}$ É este construto mecânico e o seu critério de inteligibilidade e de verdade que estão subjacentes às considerações de Kant, no prefácio à segunda edição da Crítica da Razão Pura, sobre a revolução galilaica, classificadas como uma "Revolution ihrer Denkart": Cf. E. KANT, Kritik der reinen Vernunft, "Vorrede zur zweiten Auflage", B, XIII-XIV (Hamburg, Felix Mainer Verlag, 1998, p. 19). Sobre a articulação entre o aforismo de Bacon (scientia et potentia in idem coincidunt) e a interpretação do "verum et factum convertuntur", cf. M. B. PEREIRA, "Do biocentrismo à Bioética ou da urgência de um paradigma holístico", Revista Filosófica de Coimbra, I/1 (1992), pp. 45-50.

${ }^{109}$ Cf. G. Vico, De antiquissima Italorum sapientia, Cap. 1, in: idem, Opere Filosofiche, Ed. de P. Cristofolini, Firenze, Sansono Editori, 1971, 62-74.

${ }^{110}$ F. BACON, Novum organon, P. I, aforismo 124 (Sp. I, p. 218): "Itaque ipssissimae res sunt (in hoc genere) veritas et utilitas: atque opera ipsa pluris facienda sunt, quatenus sunt veritatis pignora, quam propter vitae commoda." 
si e no seu ser, entre verdade e utilidade ${ }^{111}$, inerente ao reconhecimento da indissociabilidade entre saber e poder.

Entretanto, convém salvaguardar que este poder que a ciência proporciona deve ser enquadrado na tripla distinção operada por Bacon entre o poder pessoal, o poder da pátria e o poder do género humano, sendo exactamente este o que é visado pela Instauratio magna, que o inclui no respectivo subtítulo, uma vez que corresponde a uma ambição mais sã e mais nobre que as anteriores, e que o articula com as artes e com as ciências que, assim, obedecendo à natureza, a poderão dominar ${ }^{112}$. Reconduzindo, pois, o poder da ciência ao poder do género humano é, mais uma vez, o sujeito epistémico que é reformulado, ganhando sentido, na reforma do saber proposta, a atenção concedida à reforma das instituições, ao trabalho de cooperação e à criação de sociedades científicas, pois "a dificuldade de toda a obra pode ser superada pela amplitude da recompensa, pela rectidão da direcção e pela conjunção de esforços" 113 , não descurando mesmo a necessidade de um maior contacto internacional entre as próprias universidades ${ }^{114}$ e uma "fraternidade

${ }^{111}$ Cf. Paolo Rossi, Los filósofos y las máquinas. 1400-1700, Barcelona, Labor, 1965, pp. 139-161. Esta interpretação anti-utilitarista voltou a ser reafirmada recentemente pelo mesmo autor ("Bacon's idea of science", in: Markku PeltoneN (Ed.) - The Cambridge Companion to Bacon, pp. 25-46) ao concluir (pp. 36-37) que "things as they really are, considered not from the viewpoint of appearance but from that the existence, not in relation to man but in relation to the universe, offer conjointly truth and utility."

${ }^{112}$ F. BACON, Novum organon, P. I, aforismo 129 (Sp. I, p. 222): "Praeterea non abs re fuerit, tria hominum ambitionis genera et quasi gradus distinguere. Primum eorum, qui propriam potentiam in patria sua amplificare cupiunt; quod genus vulgare est et degener. Secundum eorum, qui patriae potentiam et imperium inter humanum genus amplificare nituntur; illud plus certe habet dignitatis, cupiditatids haud minus. Quod si quis humani generis ipsius potentiam et imperium in rerum universitatem instaurare et amplificare conetur, ea proculdubio ambitio (si modo ita vocanda sit) reliquis et sanior est et augustior. Hominis autem imperium in res, in solis artibus et scientiis ponitur. Naturae enim non imperatur, nisi parendo."

${ }^{113}$ F. BACON, The advancement of Learning, L. II (Sp. III, p. 322): "Let this ground therefore be laid, that all works overcomen by amplitude of reward, by soundness of direction, and by the conjunction of labours."

${ }^{114}$ Idem, ibidem (Sp. III, p. 327): "For as the proficience of learning consisteth much in the orders and institutions of universities in the same states and kingdoms, so it would be yet more advanced, if there were more intelligence mutual between the universities of Europe then now there is." 
no saber e nas luzes" 115 . Foi esse, aliás, o projecto societal que Bacon procurou descrever numa possível forma de efectivação prática na "utopia científico-técnica" que deixou incompleta e que intitulou New Atlantis, descrevendo a ilha de Bensalem, onde ocupa lugar de destaque uma sociedade científica intitulada Casa de Salomão, cujo objectivo é "o conhecimento das causas e dos secretos movimentos das coisas e o alargamento dos limites da mente humana para a realização de todas as coisas possíveis" 116 e que na sua estrutura organizativa se poderia designar o paradigma baconiano de uma "Fundação para a Ciência e Tecnologia". É ainda nesta sensibilidade sociológica e nesta redefinição do sujeito epistémico que se inscreve a importância dada, sobretudo em The advancement of Learning, à retórica da ciência: só a partir de uma clara consciência da dimensão dialógica da pesquisa científica é possível ensaiar, como o autor faz, a defesa de uma pluralidade de métodos de comunicação, sendo especialmente significativa a distinção entre método magistral, correspondente à lógica do adoutrinamento (ou, em termos lógico-empiristas, ao contexto da justificação) e método de iniciação, correspondente à lógica da descoberta (ou, ainda em termos lógico-empiristas, ao contexto da descoberta), com um claro primado do último, considerado então pouco seguido e desenvolvido (via deserta et interclusa ${ }^{117}$ ). Ora é

${ }^{115}$ Idem, ibidem (Sp. III, p. 327): “And surely as nature createth brotherhood in families, and arts mechanical contract brotherhoods in communalties, and the anointment of God superinduceth a brotherhood in kings and bishops; so in like manner there cannot but be a fraternity in learning and illumination, relating to that paternity which is attributed to God, who is called the Father of illuminations or lights."

${ }^{116}$ Idem, New Atlantis (Sp. III, p. 156): "The End of our Foundation is the knowledge of Causes, and secrete motions of things; and the enlarging of the bounds of Human Empire, to the effecting of all things possible." Sobre a cooperação científica como dimensão fundamental da concepção baconiana de ciência e sobre a aplicação que dela é feita na Nova Atlântida, cf. Rose-Mary SARGEnt, "Bacon as an advocate for cooperative scientific research", in: Markku Peltonen (Ed.) The Cambridge Companion to Bacon, pp. 146-171.

${ }^{117}$ F. BACON, The advancement of Learning, L. II (Sp. IV, p. 403): “"Neither is the Method or the nature of the tradition material only to the use of knowledge, but likewise to the progression of knowledge: for since the labour and life of one man cannot attain to perfection of knowledge, the wisdom of the Tradition is that which inspired the felicity of continuance and proceeding. And therefore the most real diversity of method is of method referred to Use, and method referred to 
precisamente esta reformulação da natureza do sujeito epistémico que nos permite operar um último salto e reencontrar Bachelard que, assim, também poderemos reler a uma nova luz.

\section{A Ciência operativa e a cidade dos cientistas como sujeito epistémico}

Já no seu primeiro livro, Essai sur la connaissance approchée, Bachelard anunciava a intuição que será recorrente ao longo de toda a sua obra, segundo a qual "a técnica realiza plenamente o seu objecto" ilustrando-o com o exemplo do mecanicismo, de cujo construto retira também as devidas consequências gnoseológicas e epistemológicas, fazendo repousar, agora cartesianamente e baconianamente, a sua clareza e precisão no reconhecimento de que "somos um centro produtor de forças e podemos assim vivificar, dinamizar a geometria dos movimentos que, sem isso, seriam para nós um vão espectáculo." 118 E, no mesmo ano, na sequência da referência ao carácter ontogénico do novo espírito científico ${ }^{119}$, falará das substâncias químicas como "concreção de uma força substancializante" 120 , que reflecte o "esforço criador da química moderna", designando-as mesmo "conceitos realizados" ${ }^{21}$, razão pela qual se pode concluir que "a ciência factícia ultrapassa nitidamente a ciência natural" ${ }^{122}$ sendo também a ciência física moderna cada vez

Progression; whereof the one may be termed Magistral and the other of Probation." Convém ter em conta que este Probation é traduzido por Initiativa na versão do De augmentis scientiarum (Sp. I, p. 663), com o sentido de método de iniciação à invenção. Outras divisões merecem ainda a atenção de Bacon em The Advancement of learning, como a distinção entre método de exposição por aforismos e método de exposição sistemática, ou a distinção consoante os conteúdos a transmitir (como a matemática ou a Física) ou ainda a distinção entre o novo ou excepcional e o usual ou análogo ao já conhecido. Cf. a este propósito, The Advancement of Learning, L. II (Sp. III, pp. 405-408).

${ }^{118} \mathrm{G}$. BACHELARD, Essai sur la connaissance approchée, pp. 155-156.

${ }^{119}$ Idem, Le pluralisme cohérent de la chimie moderne, p. 67: "La loi d'homologie est une loi d'ontogénie, mais d'ontogénie active, dont l'homme même fixe le plan."

${ }^{120}$ Cf. idem, ibidem, p. 68.

${ }^{121}$ Cf. idem, ibidem, p. 68.

${ }^{122}$ Cf. idem, ibidem, p. 69. 
"menos uma ciência dos factos do que uma ciência dos efeitos" E num estudo publicado em 1934, atento à importância da historicidade do conhecimento e após um confronto com os pressupostos cartesianos, dizia sintomaticamente: "O conhecimento dinamiza-se pelo próprio facto da sua historicidade. Tendo uma história, tem um destino. E esta história é pedagógica. E este destino é uma vontade técnica." 124 Mais tarde, esse poder realizador da ciência presente no "materialismo instruído", é expressamente assumido, quase em termos baconianos, como uma vontade de potência, dele se dizendo que "não sendo únicamente uma filosofia especulativa, arma uma vontade de potência, vontade que se excita pela própria potência dos meios oferecidos" $125 \mathrm{e}$ que se realiza através de algo que é, afinal, a nova tradução da "forma" como "natura naturans" de Bacon: a technique créante ${ }^{I 26}$.

${ }^{123}$ Cf. idem, ibidem, p. 229: "Voici d'ailleurs un trait bien spécial de la science physique moderne: elle devient moins une science de faits qu'une science d'effets. Quand nos théories ont permis de prévoir l'action possible d'un principe donné, nous nous acharnons à réaliser cette action."

${ }^{124}$ Idem, “Idéalisme discursif”, in: Études, Paris, J. Vrin, 1970, pp.90-91 (artigo publicado originalmente em Recherches Philosophiques, 1934-35, pp. 21-29). E algumas páginas depois articulava nestes termos o poder do sujeito com a consciência da ruptura (p. 94): "En prenant conscience de mon erreur objective, je prends conscience de ma liberté d'orientation [...] Vivant la rectification objective de la connaissance, le sujet a la révélation de sa propre puissance et de la possibilité d'un devenir spirituel."

${ }^{125} \mathrm{Cf}$. idem, Le matérialisme rationnel, p. 5. E o autor acrescenta: "Il semble que, là aussi, sur le plan psychologique, la volonté de puissance connaisse une réaction en chaîne. Plus on peut, plus on veut. Plus on veut, plus on peut." E para não dificultar a comparação com Bacon, o autor acrescenta algumas linhas depois: "'Mais, dès que l'homme s'empare effectivement des puissances de la matière, dès qu'il ne rêve plus éléments intangibles et atomes crochus, mais qu'il organise réellement des corps nouveaux et administre des forces réelles, il aborde à la volonté de puissance pourvue d'une vérification objective. Il devient magicien véridique, démon positif. Et il enseigne une magie vraie. Il enrichit l'avenir en lui conférant une volonté de puissance prouvée. De ce fait, la liaison de la volonté de puissance et de la volonté de savoir devient étroite et durable." (Sublinhado pelo autor). Algumas páginas depois, a mesma obra, destacando ainda a dinâmica criadora deste "materialismo instruído", dirá, agora em termos mais cartesianos, que ele "aumenta a ordem da natureza", "cria a ordem" (p. 22) e que mais do que "compreender uma ordem", ele "promove uma ordem" (p. 24).

${ }^{126}$ Cf. idem, ibidem, p. 199. Compreende-se, assim, que em obra publicada postumamente por G. CANGUILHEM (L'engagement rationaliste, Paris, PUF, 1972) e numa contribuição que já datava de 1949, Bachelard se refira (p. 126) ao "mundo 
Mas o mais interessante é que ao focar a ciência precisamente a partir do seu poder realizador, Bachelard tem consciência de que não é o espírito científico isolado a sede ou o sujeito do saber epistémico, mas sim aquilo a que em diversas ocasiões chama "la cité savante". É, por exemplo, no quadro das transformações dessa "cité savante" que ele procura explicar, no século XIX, a passagem de um "empirismo passivo" a um "empirismo activo e pensado" 127 , tal como é pelo recurso à categoria de uma "cité physicienne" que procura superar o idealismo de que sofrem muitas epistemologias: "O pensamento científico não pode encontrar as suas formas duras e múltiplas nesta atmosfera de solidão, neste solipsismo que é o mal congénito de todo o idealismo. Faz falta ao pensamento científico uma realidade social, o assentimento de uma cidade física e matemática." 128 E mesmo quando estuda as zonas dos obstáculos epistemológicos mais susceptíveis de uma análise em termos de psicologia individual, não deixa de sublinhar o carácter "altamente socializado" do pensamento científico ${ }^{129}$, uma vez que toda a evolução científica implica um jogo com o próprio "moi social de la culture" ${ }^{130}$. É assim inevitável a articulação do poder realizador da ciência e da técnica com o seu carácter social, sem o qual ele seria impossível: "É apenas necessário assinalar que tais conhecimentos e tais técnicas não podem adquirir-se e manipular-se senão no próprio

objectivo" nos termos seguintes que são bastante esclarecedores: "Le monde objectif est l'ensemble des faits vérifiés par la science moderne, c'est le Monde déposé par les pensées vérifiées par la science de notre temps."

${ }^{127}$ Cf. La formation de l'esprit sicentifique, p. 95.

${ }^{128}$ idem, Le rationalisme appliqué, p. 6.

${ }^{129}$ Idem, Le matérialisme rationnel, p. 51: "Certes une rationalité individuelle a de moins en moins de sens pour une philosophie rationaliste qui s'éduque au contact de la pensée scientifique, c'est-à-dire d'une pensée qu'on doit désigner maintenant comme une pensée de haute socialisation."

${ }^{130}$ Idem, ibidem, p. 76: “Or il n'y a pas, il n'y a plus, d'expérience scientifique immédiate. On ne saurait aborder une pensée scientifique nouvelle à blanc, avec un esprit non préparé, sans accomplir pour soi-même, la révolution scientifique que signe la pensée nouvelle comme un progrès de l'esprit humain, sans assumer le moi social de la culture." E quase no final da obra (p. 194), comentando os diálogos entre Hylas e Philonous de Berkeley, voltará a sublinhar a "estrutura cultural do espírito" para criticar o idealismo: "Du côté réaliste, aucune allusion à l'expérience fine, à l'expérience rectifiée. Du côté idéaliste, aucune allusion à la structure culturelle de l'esprit. Aucun des deux philosophes n'est dans l'histoire de la pensée et de l'expérience humaines." 
seio da cidade científica, no próprio espaço da cultura longamente adquirida pelos esforços de várias gerações. O carácter social da ciência - já o dissemos muitas vezes - é doravante um carácter fundamental da ciência contemporânea." 131 Mesmo a ciência pura, dirá o autor em 1950 numa sessão da Sociedade Francesa de Filosofia, "é uma ciência socializada", "pertence à psicologia" da "cité scientifique': " a cidade científica nas nossas sociedades actuais." 132

Poderá Bachelard não ter levado às suas últimas consequências esta inscrição da ciência no espaço social, de modo a conseguir explicar também sociologicamente muitos dos obstáculos epistemológicos de natureza ideológica, trabalho que Althusser procurará realizar, embora com as suas limitações e contradições, no quadro de uma filosofia histórico-materialista, mas mostrou estar atento à necessidade de reformular a natureza do sujeito epistémico no contexto de um pensamento mais vasto sobre o poder da ciência que é, afinal, o poder desse mesmo sujeito epistémico. Sabemos hoje que o exercício desse poder conduziu a relação do homem com a natureza e com os outros homens por caminhos que Bacon não podia suspeitar e que Bachelard terá pelo menos pressentido quando, no final da sua conferência no Palais de la Découverte, em 1951, disse enigmaticamente: "O historiador das ciências, caminhando ao longo de um passado obscuro, deve ajudar os espíritos a tomar consciência do valor profundamente humano da ciência de hoje." 133

Falar-se-á, no anunciado fim da Modernidade, de uma segunda ruptura epistemológica ${ }^{134}$. Mas talvez tanto não seja necessário. $\mathrm{Ou}$ talvez aquilo que se pretende exprimir com essa categoria seja mais uma "ruptura ético-política", do que propriamente uma "ruptura

${ }^{131}$ Idem, ibidem,p. 175. Esta cidade científica é tanto mais necessária, quanto é ela que organiza as próprias especializações e, assim determina o espírito científico (cf. idem, ibidem, p. 208).

${ }^{132} \mathrm{Cf}$. idem, "De la nature du rationalisme", in: L'engagement rationaliste, p. 54 .

${ }^{133}$ Idem, “L'actualité de l'histoire des sciences", in: L'engagement rationaliste, p. 152.

${ }^{134}$ Cf. Boaventura de Sousa SAntos, Um discurso sobre as ciências, $4^{\mathrm{a}}$ edição, Porto, Edições Afrontamento, 1990, pp. 55-58; idem, Introdução a uma ciência pós-moderna, $2^{\text {a }}$ edição, Porto, Edições Afrontamento, 1990, pp. 36-49; idem, A crítica da razão indolente. Contra o desperdício da experiência, pp. 100-109. 
epistemológica", uma vez que o que se reivindica para a "novíssima cidade científica" é sobretudo a phronesis aristotélica ${ }^{135}$. Afinal, tudo seria diferente se o homem, ao longo da Modernidade e no exercício do seu poder, tivesse ouvido integralmente o conselho de Bacon e, como "ministro e intérprete da natureza", aprendesse que ela não pode ser dominada sem ser respeitada e obedecida, pois "natura enim non nisi parendo vincitur" 136

${ }^{135}$ É interessante verificar que no desenvolvimento que é dado a este tema por Boaventura de Sousa SAnTos em A crítica da razão indolente. Contra o desperdício da experiência, o que se acrescenta relativamente à abordagem feita em Um discurso sobre as ciências diz fundamentalmente respeito a outras dimensões que não a dimensão estritamente epistemológica, falando-se agora (pp. 104-109) de um novo senso comum ético, que é um senso comum solidário, de um novo senso comum político, que é um senso comum participativo, e de um novo senso comum estético, que é um senso comum reencantado, não se descortinando o que poderá ser, para além de eventualmente mais esclarecido, o novo senso comum epistemológico. Mesmo a sua definição como "emancipatório" ou "conhecimento prudente para uma vida decente" situam-se prioritariamente no registo ético-político. Quanto à definição desta segunda ruptura epistemológica como a transformação do conhecimento científico num novo senso comum, em termos estritamente epistemológicos, ela pouco acrescenta ao projecto iluminista de escolarização progressiva da sociedade e de democratização da ciência e da cultura.

${ }^{136}$ F. BACON, Novum Organon, P. I, aforismo 3 (Sp. I, p. 157). 